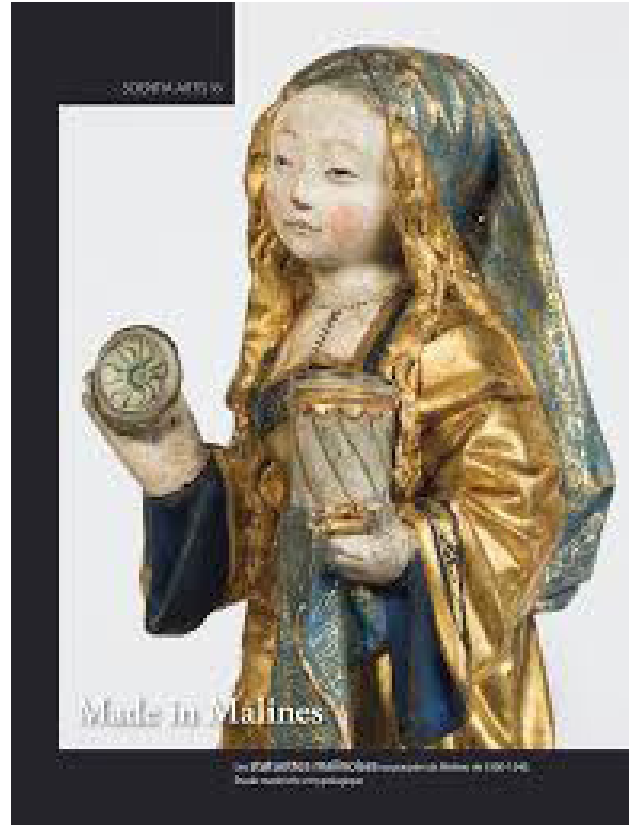

\section{Made in Malines. Les Statuettes Malinoises Ou Poupees de Malines de 1500-1540 : Etude Materielle Et Typologique}

\author{
Fanny Cayron, Delphine Steyaert \\ Institut royal du Patrimoine artistique. Bruxelles 2019
}

ISBN 978-2-930054-37-7

Dimensiones: $29,30 \times 22 \mathrm{~cm}$

Páginas: 231

Idioma: Francés
El número 16 de 'Sciencia Artis', del Instituto Real del Patrimonio Artístico (IRPA), titulado "Made in Malines. Les statuettes malinoises ou poupées de Malines de 1500 - 1540: Étude matérielle et typologique", refleja la investigación sobre las pequeñas esculturas de Malinas realizadas durante el siglo XVI. Este trabajo fue promovido por Myriam SerckDewaide, entonces directora general de esta institución, con el fin de revisar y catalogar el amplio corpus elaborado por Willy Godenne y publicado en la segunda mitad del siglo XX. Dicha investigación ha sido subvencionada por la Oficina Federal de Política Científica de Bélgica (Belspo). Forma parte de los programas de estudio y difusión de datos científicos sobre los materiales y las técnicas empleados en el arte belga. El estudio se basa en la experiencia del taller de conservación especializado en la escultura de madera policromada del IRPA, como indica su actual responsable Emmanuelle Mercier.

El libro se estructura en cinco capítulos, que abordan sucesivamente el contexto de producción de estas esculturas manufacturadas en los talleres de Malinas, su comercialización y uso devocional. Se inicia con los datos extraídos de la historiografía, para luego entrar en el análisis sistemático de la escultura, la policromía y las marcas. Estas populares esculturitas, conocidas como muñecas de Malinas o malinenses por su tamaño, aire infantil y caras redondeadas, su sonrisa y la coquetería de su hechura, estaban destinadas a la devoción privada. Representan un fenómeno esencial del arte medieval asentado en la repetición de modelos establecidos, sin buscar privilegiar el carácter original de la obra única. Entre sus características principales destacan su reducido tamaño, generalmente entre 26 y $38 \mathrm{~cm}$, y que representan figuras de santos, el niño Jesús o la Virgen con el Niño como las más extendidas.

Sobre la base del Corpus estudiado de estas pequeñas esculturas, con más de 600 entradas, las autoras amplían la división de las dos fases de producción identificadas hasta ahora: las policromadas en Bruselas y, más tarde, la mayoría talladas y policromadas en Malinas. Como consecuencia del sistemático análisis formal y técnico de la talla, la policromía y las marcas de control características de los centros de producción de esta época en las Países Bajos del sur, se propone la subdivisión de la segunda fase en tres periodos de acuerdo a la evolución estilística observada.

En la primera etapa, periodo Malinas-Bruselas, entre 1500 y 1510, están las obras de colaboración entre escultores de Malinas y policromadores de Bruselas, con clara influencia de la escultura bruselense y en especial de la saga de los Borman, y una policromía a base de dorados, plateados y la utilización casi sistemática del brocado aplicado.

Continúa un periodo de transición de mayor variedad de estilo y calidad, en el que si bien se mantienen rasgos de la escultura bruselense las piezas serán enteramente realizadas en Malinas, como revelan las marcas de garantía, conviviendo en su policromía brocados aplicados, estofados, esgrafiados y labores de punzonado.

La tercera fase, denominada periodo de intensificación, presenta un considerable incremento en la producción, fijará las fórmulas con un tratamiento más sofisticado en las formas, con predominio del estofado pintado y fondos punzonados en su policromía. 
El final de la producción de estas esculturitas de estilo gótico tardío supuso una menor calidad de las piezas por repetición de las fórmulas, si bien los estofados a punta de pincel con fondos punzonados siguen siendo de buena calidad.

El capítulo cuatro describe y analiza en profundidad las marcas de control del gremio y las utilizadas por escultores y policromadores, tan habituales en los centros brabanzones de la época. Sin duda, un elemento que en buena medida contribuye a identificar la procedencia y aproximar la datación de las piezas.

En el quinto capítulo se exponen una serie de aspectos que invitan a reflexionar sobre las posibilidades de colaboración y datación en torno a la producción de éstas y otras esculturas en madera policromada realizadas en los Países Bajos, y las ordenanzas de los gremios que controlaban la calidad de su manufactura. El libro finaliza con unas conclusiones claras y bien estructuradas, en las que se condensan los aspectos mencionados anteriormente.

Este volumen va destinado a conservadores-restauradores, historiadores y científicos especializados en el estudio de la escultura policromada, que trabajan en instituciones culturales, y a otros profesionales interesados en esta materia.

Cabe resaltar así mismo el valor de la documentación gráfica que incluye la publicación, con numerosos detalles de las esculturas, de la minuciosa policromía y de las marcas, como otra de las aportaciones sustantivas de este tipo de trabajos interdisciplinares que ahondan en la materialidad de los objetos estudiados.

Ana Carrassón y Marisa Gómez Instituto del Patrimonio Cultural de España (IPCE)

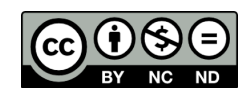

https://doi.org/10.37558/gec.v17i1.778 